\title{
DISCRETE, CONTINUOUS, DELTA, NABLA, AND DIAMOND-ALPHA OPIAL INEQUALITIES
}

\author{
Martin J. Bohner, Ramy R. Mahmoud And SAmir H. SAKer
}

Abstract. In this paper, we prove some new diamond-alpha dynamic inequalities of Opial type with one and with two weight functions on time scales. These results contain as special cases improvements of results given in the literature, and these improvements are new even in the important discrete case.

Mathematics subject classification (2010): 39A10, 39A12, $26 \mathrm{D} 15$.

Keywords and phrases: Time scales, diamond-alpha derivatives, Opial's inequality.

\section{REFERENCES}

[1] R. Agarwal, M. Bohner, And A. Peterson, Inequalities on time scales: A survey, Math. Inequal. Appl., 4 (4): 535-557, 2001.

[2] R. P. Agarwal And P. Y. H. PAng, Opial Inequalities with Applications in Differential and Difference Equations, Kluwer Academic Publishers, Dordrecht, 1995.

[3] N. Atasever, B. Kaymakçalan, G. Lešaja, And K. TAş, Generalized diamond- $\alpha$ dynamic Opial inequalities, Adv. Difference Equ., pages 2012: 109, 9, 2012.

[4] P. R. BeES ACK, On an integral inequality of Z. Opial, Trans. Amer. Math. Soc., 104: 470-475, 1962.

[5] M. Bohner AND O. DumAn, Opial-type inequalities for diamond-alpha derivatives and integrals on time scales, Differ. Equ. Dyn. Syst., 18 (1-2): 229-237, 2010.

[6] M. Bohner And B. KaymakÇAlan, Opial inequalities on time scales, Ann. Polon. Math., 77 (1): $11-20,2001$.

[7] M. Bohner And A. Peterson, Dynamic Equations on Time Scales: An Introduction with Applications, Birkhäuser, Boston, 2001.

[8] M. Bohner And A. Peterson, Advances in Dynamic Equations on Time Scales, Birkhäuser, Boston, 2003.

[9] B. KARPuZ, B. KAYMAKÇALAN, AND Ö. ÖCALAN, A generalization of Opial's inequality and applications to second-order dynamic equations, Differ. Equ. Dyn. Syst., 18 (1-2): 11-18, 2010.

[10] A. LAsota, A discrete boundary value problem, Ann. Polon. Math., 20: 183-190, 1968.

[11] D. MOZYRSKA AND D. F. M. TORRES, A study of diamond-alpha dynamic equations on regular time scales, Afr. Diaspora J. Math. (N.S.), 8 (1): 35-47, 2009.

[12] Z. Olech, A simple proof of a certain result of Z. Opial, Ann. Polon. Math., 8: 61-63, 1960.

[13] Z. Opial, Sur une inégalité, Ann. Polon. Math., 8: 29-32, 1960.

[14] S. H. SAKER, Applications of Opial and Wirtinger inequalities on zeros of third order differential equations, Dynam. Systems Appl., 20 (4): 479-494, 2011.

[15] S. H. SAKER, Lyapunov type inequalities for a second order differential equation with a damping term, Ann. Polon. Math., 103 (1): 37-57, 2011.

[16] S. H. SAKER, Lyapunov's type inequalities for fourth-order differential equations, Abstr. Appl. Anal., pages Art. ID 795825, 25, 2012.

[17] S. H. SAKER, New inequalities of Opial's type on time scales and some of their applications, Discrete Dyn. Nat. Soc., pages Art. ID 362526, 23, 2012.

[18] S. H. SAKER, Opial's type inequalities on time scales and some applications, Ann. Polon. Math., 104 (3): 243-260, 2012. 
[19] S. H. S AKER, Applications of Opial inequalities on time scales on dynamic equations with damping terms, Math. Comput. Modelling, 58 (11-12): 1777-1790, 2013.

[20] S. H. SAKER, R. P. AGARWAL, AND D. O'REgAn, Gaps between zeros of second-order half-linear differential equations, Appl. Math. Comput., 219 (3): 875-885, 2012.

[21] S. H. SAKer, R. P. Agarwal, AND D. O'REgan, New gaps between zeros of fourth-order differential equations via Opial inequalities, J. Inequal. Appl., pages 2012: 182, 19, 2012.

[22] S. H. Saker, R. P. Agarwal, AND D. O'Regan, Properties of solutions of fourth-order differential equations with boundary conditions, J. Inequal. Appl., pages 2013: 278, 15, 2013.

[23] Q. Sheng, M. Fadag, J. Henderson, And J. M. Davis, An exploration of combined dynamic derivatives on time scales and their applications, Nonlinear Anal. Real World Appl., 7 (3): 395-413, 2006.

[24] J. S. W. Wong, A discrete analogue of Opial's inequality, Canad. Math. Bull., 10: 115-118, 1967.

[25] Z. ZhaO, Y. XU, AND Y. LI, Dynamic inequalities on time scales, Int. J. Pure Appl. Math., 22 (1): 51-58, 2005. 